\title{
PERAN PEDAGANG KAKI LIMA (PKL) DALAM MENINGKATKAN KESEJAHTERAAN KELUARGA \\ (Studi di Kawasan Objek Wisata Pantai Mutiara Desa \\ Gumanano Kecamatan Mawasangka Kabupaten Buton \\ Tengah)
}

Nazrin $^{1}$, La Ode Monto Bauto ${ }^{2}$, Bakri Yusuf ${ }^{3}$

${ }^{123}$ Fakultas Ilmu Sosial dan Ilmu Politik Universitas Halu Oleo

E-mail: nazrinkesos91@gmail.com, laodemonto@yahoo.co.id, bakriyusuf0811@gmail.com

do) $10.52423 /$ well-being.v2i1.20009

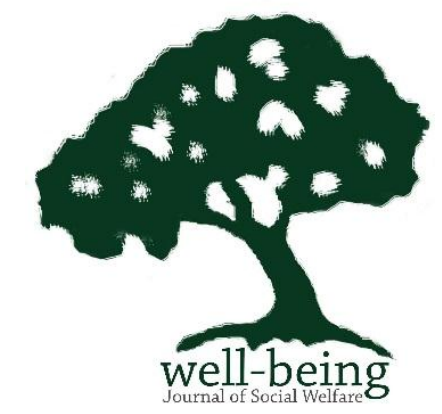

This research aims to determine the role and constraints of street vendors in improving family welfare in the Pantai Mutiara tourist attraction area, Gumanano Village, Mawasangka District, Central Buton Regency. This type of research is qualitative research. Data collection techniques were carried out by means of observation, interviews and documentation with 9 main informants of street vendors (PKL) in the Pantai Mutiara Tourism Object, Gumanano Village, Mawasangka District, Central Buton Regency and 5 people as supporting informants. The results showed that first, the role of street vendors (PKL) in improving family welfare in the Pantai Mutiara tourist area, namely increasing family income in meeting the needs of food, clothing, shelter, health, and educational needs. The two obstacles faced by street vendors in improving family welfare are physical capital, knowledge and skills.

Keywords: Role, Street Vendors, Family Welfare.

\section{PENDAHULUAN}

Indonesia merupakan negara berkembang yang mempunyai jumlah penduduk yang besar. Pertumbuhan penduduk yang tinggi menyebabkan ketidakseimbangan antara permintaan tenaga kerja dan penawaran tenaga kerja di Indonesia.Hal ini menimbulkan berbagai masalah karena daya dukung ekonomi yang dimiliki terbatas. Daya dukung tersebut antara lain kurangnya penyediaan lapangan kerja yang berakibat pada adanya pengangguran, rendahnya tingkat pendapatan penduduk per kapita dan tidak meratanya tingkat pendapatan masyarakat (Siswanto, 2013).

Populasi penduduk yang tinggi di satu sisi berdampak baik terhadap perekonomian tapi di sisi lain juga memberikan dampak buruk. Dampak baiknya jika pertumbuhan penduduk yang besar menjadi peluang terhadap tumbuhnya pasar domestik sehingga bisa meningkatkan penyerapan angkatan kerja. Sebaliknya akan berdampak buruk jika pertumbuhan penduduk yang besar tidak diimbangi dengan ketersediaan lapangan kerja yang mencukupi karena selain menimbulkan pengangguran juga mengakibatkan bertambahnya penduduk miskin dan pada akhirnya terjadi masalahmasalah sosial (Susilo, 2011).

Meningkatnya jumah tenaga kerja yang tidak seimbang dengan penyediaan lapangan pekerjaan formal, mengakibatkan bertambah besarnya angka pengangguran.Hal ini menyebabkan banyak tenaga kerja yang kemudian bekerja atau berusaha di sektor informal. Sektor informal atau pedagang kaki lima berperan cukup penting dalam pengembangan masyarakat dan pembangunan nasional, karena ketika program pembangunan kurang mampu menyediakan peluang kerja bagi angkatan 
kerja, pedagang kaki lima dapat berperan sebagai alternatif peluang kerja bagi para pekerja yang tidak terserap di sektor formal (Damayanti, 2011).

Pedagang Kaki Lima (PKL) adalah pedagang dengan modal relatif kecil dan berusaha dibidang produksi dan penjualan barang-barang (jasa-jasa) untuk memenuhi kebutuhan kelompok tertentu di dalam masyarakat, dan usaha tersebutbiasanya dilaksanakan pada tempat-tempat yang diangap strategis (Hariningsih dkk, 2008).PKL juga menguntungkan bagi konsumen dari masyarakat ekonomi menengah kebawah, karena PKL mampu menyediakan barang-barang kebutuhan dengan harga yang relatif murah.

Undang-Undang No 11 Tahun 2009 tentang Kesejahteraan Sosial, Pasal 1 ayat 1 yang berbunyi "kesejahteraan sosial ialah kondisi terpenuhinya kebutuhan material, spiritual, dan sosial warga negara agar dapat hidup layak dan mampu mengembangkan diri, sehingga dapat melaksanakan fungsi sosialnya".

Dalam rangka memenuhi kebutuhan hidup sejahtera, suatu keluarga yang mempunyai kemampuan dan jeli melihat potensi diri serta mampu mengidentifikasi lingkungan, dapat menemukan peluang dan membuka peluang usaha bagi masyarakat.Dengan adanya peluang usaha tersebut, diharapkan dapat membantu pertumbuhan ekonomi masyarakat sekitar menjadi lebih baik sehingga mampu mengurangi tingkat urbanisasi yang tinggi.Selain itu dengan adanya usaha yang menitik beratkan pada peluang yang ada di daerah sekitar, diharapkan mampu menjadi ikon atau ciri khas dari daerah tersebut.

Desa Gumanano merupakan salah satu desa dari 17 desa di Kecamatan Mawasangka Kabupaten Buton Tengah yang berdiri sejak tahun 1997 dengan luas wilayah $7 \mathrm{~km} 2$. Desa ini mempunyai jarak
$17 \mathrm{Km}$ dari Ibu Kota Kecamatan Mawasangka yakni Mawasangka.Desa Gumanano yang di kenal dengan pariwisatanya kini membuka peluang bagi masyarakt setempat, untuk membuka usaha.Hadirnya pariwisata Pantai Mutiara Di Desa Gumanano, kini masyarakat setempat memanfaatkan peluang untuk membuka usahapedagang kaki lima (PKL).

Para pedagang kaki lima yang berdagang di kawasan objek wisata Pantai Mutiara, di latar belakangi oleh kekurangan ekonomi atau rerata keluarga yang tidak mampu. Desakan kebutuhan dan dengan himpitan kekurangan ekonomi untuk biaya sandang, pangan, papan, kesehatan dan pendidikan, mengharuskan bagi mereka untuk berusaha demi memenuhi kebutuhan atau kesejahteraan keluarga. Beberapa masyarakat desa gumanano memanfaatkan peluang melalui pariwisata untuk membuka usaha seperti Pedagang Kaki Lima (PKL).

Berdasarkan observasi awal yang di lakukan peneliti di lokasi penelitian yang berada dikawasan objek wisata pantai mutiara desa Gumanano Kecamatan Mawasangka Kabupaten Buton Tengah, terdapat beberapa pedagang kaki lima yang berjualan dengan menggunakan gerobak dengan jenis barang jualan seperti makan ringan, air mineral, rokok.

Berdasarkan dari uraian latar belakang masalah di atas maka peneliti tertarik untuk melakukan penelitian dengan judul: "Peran Pedagang Kaki Lima (PKL) Dalam Meningkatkan Kesejahteraan Keluarga di Kawasan Pariwisata Pantai Mutiara Desa Gumanano, Kecamatan Mawasangka, Kabupaten Buton Tengah".

\section{METODE PENELITIAN}

Penelitian ini di laksanakan di kawasan objek wisata Pantai Mutiara Desa Gumanano, Kecamatan Mawasangka, Kabupaten Buton Tengah. Pertimbangan Peneliti memilih dan menetapkan lokasi 
penelitian ini, dengan alasan bahwa Desa Gumanano merupakan salah satu desa yang memiliki potensi di Kecamatan Mawasangka karna objek wisatanya yang begitu memukau hingga menarik perhatian masyarakat luar untuk datang berkunjung, menikmati panorama keindahan wisatanya, dandi kawasan wisata tersebut terdapatmasyarakat yang mengembangkan usaha pedagang kaki lima (PKL).

Penelitian yang digunakan adalah jenis penelitian kualitatif. Penelitian kualitatif adalah penelitian yang bertujuan memahami realitas sosial, yaitu melihat dunia dari apa adanya, bukan dunia seharusnya, maka seorang peneliti kualitatif haruslah orang yang memiliki open minded. Karenanya, melakukan penelitian kualitatif dengan baik dan benar berarti telah memiliki jendela untuk memahami dunia psikologis dan realita sosial.Penelitian kualitatif sebagai human instrument, yakni berfungsi menetapkan fokus penelitian, memilih informasi sebagai sumber data, melakukan pengumpulan data, menilai kualitas data, analisis data, menafsirkan data dan membuat kesimpulan atas temuannya (Sugiono, 2008).

Penelitian kualitatif memusatkan perhatian pada prinsip-prinsip umum yang mendasari perwujudan sebuah makna dari gejala-gejala sosial dan budaya dengan menggunakan kebudayaan dari masyarakat bersangkutan untuk memperoleh gambaran mengenai kategorisasi tertentu. Berdasarkan pandangan tersebut, peneliti kualitatif dalam penelitian ini dimaksudkan untuk mencarisebuah sebuah fakta, kemudian memberikan penjelasan yang ditemukan dilapangan.

Penentuan informan dalam penelitian ini menggunakan teknik purposive sampling, yaitu pemilihan informan dengan pertimbangan tertentu.Dengan anggapan bahwa informan paling mengerti tentang informasi yang peneliti harapkan sehingga memudahkan peneliti menjelajahi objek atau situasi sosial tertentu.Adapun Informan dalam penelitian ini adalah :

1. Pelaku usaha sektor informal (PKL)

2. Koordinator Pengelola objek wisata pantai Mutiara

3. Kepala Desa Gumanano

4. Pengunjung objek wisata

\section{HASIL DAN PEMBAHASAN}

1. Peran Pedagang Kaki Lima (PKL) Dalam Meningkatkan Kesejahteraan Keluarga di Kawasan Objek Wisata Pantai Mutiara Desa Gumanano Kecamatan Mawasangka Kabupaten Buton Tengah

1. Meningkatkan pendapatan keluarga

a) Kebutuhan Pangan

Kebutuhan pangan yaitu kebutuhan akan makanan. Usaha untuk mewujudkanketahanan pangan pada tingkat keluarga atau rumah tangga dapat ditempuh melaluiberbagai jenis kegiatan seperti usaha pedagang kaki lima (PKL).

Berdasarkan hasil wawancara dengan Ibu Hadija yang berusia 40 tahun secara keseluruhan sebagai berikut:

"Pertama, sebelum saya buka usaha pedagang kaki lima (PKL) ini dek, saya biasa menenun juga di rumah hitunghitung untuk membantu suami dengan pendapatan satu bulan $\mathrm{Rp}$ 420.000. Tapi, kenapa saya membuka usaha di pantai mutiara ini, karna awalnya dek saya melihat banyak pendatang di pantai ini maka ini merupakan peluang untuk buka usaha kecilkecilan karna otomatis mereka pasti akan belanja. Modal untuk usaha saya ini semuanya satu juta lima ratus ribu rupia $(\mathrm{Rp}$ 
1.500.000). dan saya berjualan disini sudah 1 tahun lebih.Untuk waktu jualan satu minggu tiga kali dibuka yaitu dari jum'at sampai minggu bukanya dari jam 08:00 sampai 17:00 sore hari, setelah itu tdak buka lagi. Alhamdulillah pendapatan dari usaha pkl selama satu bulan Rp 300.000 sedikit membantu untuk pemenuhan kebutuhan keluarga."(wawancara dengan Ibu Hadija 27 September 2020)

Berdasarkan

hasil wawancara,Informan mengatakan bahwa sebelum bekerja sebagai pengusaha pedagang kaki lima (PKL), informan (Ibu Hadija) biasa menenun di rumahnya hitung-hitung katanya untuk membantu pendapatan suami dalam pemenuhan pendapatan keluarga dari pendapatan hasil tenunnya yaitu sebesar Rp 420.000. dengan pendapatan dari hasil usaha pedagang kaki lima (PKL) informan menyatakan membantu terhadap pemenuhan kesejahteraan keluarga, berdasarkan kesimpulan infoman tersebut, maka peneliti menyimpulkan bahwa dengan pendapatan Rp. 300. 000 dari hasil usaha PKL yang di jalankan informan memberikan kontribusi terhadap perekonomian keluarga dilihat dari sudut pandang terpenuhinya kebutuhan pangan.

\section{b) Memenuhi kebutuhan Sandang dan Papan}

Kebutuhan sandang dan papan adalah kebutuhan akan pakaian dan tempattinggal. Pakaian dan rumah merupakan sarana untuk mewujudkan pemenuhankebutuhan sosial psikologis keluarga dan anggotanya.kualitas dan kuantitas dalampemilihan sandang dan papan akan berpengaruh pada tingkat kesejahteraan keluarga.

Dari hasil observasi peneliti, pemenuhan kebutuhan sandang dan papanpada informan penelitian sudah terpenuhi dengan baik meski tidak seluruhnya sepertiapa yang diinginkan, beberapa dari informan peneliti ada yang mempunyai rumah yangdibangun secara permanen (rumah beton/ semen), namun ada pula yang bangunan rumahnya terbuat dari papan.

Seperti yang disampaikan oleh Ibu wa nguna berikut pernyataannya adalah :

"Saya menjalankan usaha ini dek sudah lama mungkin sudah ada 2 tahun lebih.Mau bagaimana lagi kalau tidak membuka usaha bigini, saya tidak tau mau mendapatkan uang dari mana.Saya disini juga tinggal sendiri, mengurus rumah sendiri karena anak saya dua orang sudah berkeluarga sementara berharap mereka juga hidup paspasan.suami saya kurang lebih satu tahun meninggal, mau tidak mau yahh harus menjalani keadaan seperti ini. Alhamdulillah meski rumah papan yang penting nyaman dek, untuk rumah yang saya tempati milik sendiri.

Saya biasa buka berdagangdari pukul 08:00 pagi sampai 17:00 sore itupun dalam satu minggu kadang hanya hari minggu saja saya buka.Untuk pendapatan dari usaha pkl ini Rp 400.000 Allhamdulillah kadang mencukupi kadang tidak mencukupi, dari pendapatan ini di pergunakan untuk kebutuhan 
rumah tangga, perbaikan rumah sperti lebaran itu di cet baru laagi atau juga kebutan hari-hari. dalam satu minggu nanti tinggal di putar-putar untuk beli bahanbahan jualan lagi."(wawancara 04 oktober 2020).

Berdasarkan hasil wawancara, dengan usaha pedagang kaki lima yang informan lakukan dengan nominal pendaapatan Rp 400.000 per bulan dansudah dua tahun lebih informan menjalankan usahanya, sudah dapatmemenuhi kebutuhan hidupnya sehari hari termasuk biaya tempat tinggalnya atau kadang juga tidak mencukupi tutur informan,pendapatan yang didapatkan per bulan dari berjualan tersebut adalah sekitarRp 400.000. dari hasil PKL inilah informan mempergunakan untuk pemenuhan kebutuhan seharihari termasuk kebutuhan listrik dan rumahnya.

\section{c). Kebutuhan Kesehatan}

Kesehatan adalah keadaan sejahtera dari badan, jiwa dan sosial yangmemungkinkan setiap orang hidup produktif secara sosial dan ekonomi (UU Kesehatan No 23,1992). Oleh karena itu kesehatanmerupakan hal yang sangat penting untuk diperhatikan karena akan mendasari peningkatankualitas dan kuantitas hidup dalam masyarakat.Upaya dalam meningkatkan kualitas hidup manusia dalam bidangkesehatandi masa sekarang sangatlah penting. Dari itu, usaha Pedagang Kaki Lima (PKL) yang di jalankan informan tidak sebatas untuk pemenuhan sandang, pangan dan papan saja, melainkan juga dapat membendung kebutuhan kesehatan melalui tabungan hasil pendapatan dari usaha pedagang kaki lima (PKL).

Berdasarkan hasil wawancara
dengan Bapak Rahmat, berikut
pernyataannya:

"untuk biaya kesehatan, Alhamdulillah bisa ditutupi dengan hasil usaha PKL ini. Soalnya istri saya juga baru melahirkan beberapa bulan yang lalu dan untuk beli susu dan makanannya ya dari usaha PKL ini kita pake di bantu juga usaha meminjamkan ban juga"

Berdasarkan hasil wawancara dengan informan Bapak Rahmat, peneliti menemukan bahwa dari usaha Pedagang Kaki Limanya dapat menutupi kebutuhan kesehatan sebab berdasarkan keterangan informan yang menyatakan terkait biaya perawatan (pelahiran) anaknya di biayai dari hasil pedagang kaki lima (PKL) nya. Hingga dapat disimpulkan bahwa usaha Pedagang Kaki Lima yang di jalankan oleh informan telah dapat memberikan kontribusi terhadap pemenuhan bagianbagian indikator kesejahteraan yaitu bidang kesehatan.Seseorang dapat di katakana berfungsi secara sosial, manakalah dapat menyelesaikan permasalahannya sendiri, seperti yang di alami oleh informan, dimana informan sebagai kepala rumah tangga telah dapat memenuhi kebutuhan kesejahteraan di bagian kesehatan.

\section{d). Kebutuhan Pendidikan}

Usaha mencerdaskan kehidupan bangsa lewat proses pendidikan dan pembudayaan bukan saja penting sebagai cara memanusiakan manusia, tetapi juga memiliki nilai pragmatik dalam mengembangkan kesejahteraan rakyat. "Kemajuan sebuah bangsa terletak pada pendidikan dan para generasi bangsa itu sendiri," kata Ki 
Hadjar Dewantara suatu kali.Baginya, pendidikan merupakan wahana untuk membuat bangsa ini menjadi bangsa yang maju, bermartabat, sejahtera, dan merdeka lahir-batin.Singkat kata, pendidikan menjadi hal paling vital, merupakan kunci utama bagi kemajuan dan kesejahteraan sebuah bangsa dan umat manusia.

Berdasarkan hasil wawancara dengan informan Ibu Rumisa, berikut keterangannya:

"alhamdulillah saya dapat menyekolahkan anak saya sampai SMK, untuk biaya buku dan uang jajan hari-hari dari hasil PKL ini. Untuk kuliah Tidak mencukui dek karna biayanya sangat tinggiinipun untu SMK bakubantu sama bapaknya, karna keterbatasan ekonomi pas lulusnya terpaksa anak pertama saya kasih merantau.

Berdasarkan hasil wawancara diatas, peneliti menyimpulkan berdasarkan keterangan informan, bahwa dari hasil pendapatan pedagang kaki lima (PKL) tidak sepenuhnya dapat memenuhi kebutuhan dalam hal pendidikan, dimana informan hanya mampu menyekolahkan anaknya samapai pada tingkat sekolah menengah atas. Sehingga dapat di tarik kesimpulan bahwa hasil pedagang kaki lima (PKL) informan (Ibu rumisa) hanya mampu memenihi kebutuahan pendidikan anak sampai pada sekolah menengah atas, namun tidak mencukupi dalam pemenuhan kebutuhan pendidikan anaknya sampai pada pendidikan tinggi berhubung keterbatasan ekonomi keluarga.

\subsection{Kendala-Kendala Yang Dihadapi Pedagang Kaki Lima Dalam Meningkatkan \\ Keluarga \\ 1. Faktor modal fisik}

Kita ketahui bahwa salah satu yang menjadi penghambat dalam menjalankanusaha adalah modal yang kurang.Modal usaha merupakan hal utama yang diperlukanuntuk mengembangkan atau membangun usaha jualan.Pada umumnya keluarga yang membuka usaha pedagang kaki lima (PKL) di Desa gumanano Kecamatan Mawasangka yang menjalankan usaha pedagang kaki lima (PKL) yang memilikipenghasilan yang masih rendah mendapatkan kesulitan dalam pengembangan usahamereka karena hanya memiliki modal yang kurang sehingga mereka menjalankanusaha dengan seadanya saja.

Sebagimana yang dikemukakan oleh informan Wa Asa yang berusia 52 tahun berikut:

"Kendala saya dalam berjualan usaha ini modal, andai saja modal sayabanyak saya ingin membuka usaha atau menambah jenis jualan saya dan merubah tempat jualan saya seperti juga buatkan tempat duduk untuk pembeli ini.Modal saya itu hanya sekitar Rp.1000.000 saja, ini saja untuk tempat jualan hanya bermodalkan papan bekas seadanya berbeda dengan penjual lain yang dapat bantuan gerobak jualan dari."(wawancara 04 oktober 2020). 
Informan Wa Asa adalah istri dari buruh tani beliau berumur 52 tahun danmempunyai anggota keluarga sebanyak lima orang termasuk suami dan 3 oranganaknya. Pendidikan informan tidak tamat di bangku sekolah dasar itu semua karena darilatar belakang keluarga informan yang kondisi ekonominya kurang mampu untuk biayasekolah karena sebagian hasil jerih payah yang mereka dapatkan hanya untukmemenuhi kebutuhan sehari-hari itupun juga pada saat itu sekolah sangat jauh untuk di jangkau.

Berdasarkan hasil wawancara, informan mengatakan bahwakendala yang dihadapi adalah kurangnya modal Usaha. Modal usahanya hanya berkisar Rp 1.000.000an saja.Jika seandainya memiliki modal banyak dia menginginkanmemperbanyak jenis jualannya dan merombak tempat usahanya dengan tempat yang lebih layak semisal juga membuatkan tempat dudukk atau istrahat bagi para pembeli, sehingga peneliti menyimpulkan bahwa berdasarkan teori kendala modal fisik sangat mempengaruhi para pedagang kaki lima (PKL).

\section{Faktor Pengetahuan}

Pengetahuan merupakan sesuatu hal yang penting bagi setiap manusia.Setiap manusia membutuhkan pengetahuan khususnya bagi pedagang yaitu, misalnya pengetahuan tentang tata kelola usahanya untuk meningkatkan pendapatan dengan menarik perhatian para pembeli, pengetahuan tersebut dapat di peroleh baik pendidikan formal maupun pendidikan informal, serta non formal.Dengan memiliki wawasan atau pengetahuan yang luas dan pola pikir yang maju hal demikian dapat mempengaruhi kesempatan bagi manusia untuk memilih dan mengembangkan jenis pekerjaan guna memenuhi kebutuhan hidupnya.

Sebagaimana yang di sampaikan oleh bapak rahmat terkait kendala selama dalam menjalankan usaha pkl yaitu:

"kendala saya dalam menjalankan usaha saya ini pertama soal modal, modal saya bangun usaha ini $\mathrm{Rp}$ 8.000.000 itu saya utang, di gunakan untuk beli mesin generator jadi awalnya setiap pendapat dari usaha ini sebagian kami sisihkan untuk bayar utang selebihnya untuk kebutuhan harihari.selain itu pengetahuan juga iya karna saya sekolah juga hanya sampai SMP saja"(wawancara 11 oktober 2020).

Berdasarkan keterangan informan di atas, peneliti menyimpulkan bahwa kendala yang di alami dalam menjalankan usaha pedagang kaki lima (PKL) informan utamanya factor modal finansial, dimana informan meminjam uang berkisar $\mathrm{Rp} 8.000 .000$ untuk modal awal membuka usahanya. Informan membeli mesin generator untuk menunjungan usahanya yaitu sebagai penjual es, terlepas dari situ untuk pendapatan informan biasa membaginya untuk kebutuhan hari dan juga bayar utang. Selain factor modal, peneliti juga menyimpulkan bahwa informan bahwa juga mengalami kendala lain yang di alaminya adalah factor pengetahuan, dimana informan hanya menempuh sekolah menengah pertama (SMP).

\section{Faktor keterampilan.}

Bekal pengetahuan saja tidaklah cukup jika tidak dilengkapi dengan bekal keterampilan.keterampilan juga mempengaruhi kemajuan suatu usaha 
missal dalam memasarkan dagangan, berkomunikasi dan berinteraksi.

seperti yang di kemukakan oleh informan, berikut keteranganya:

“ibu ini tidak sekolah dek jadi ibu tidak tau untuk jualan, ibu dari dulu jualannya begini-begini saja dek seadanya saja, kalaupun juga harus di ubah kecuali harus ada modal uang juga."(wawancara 11 oktober 2020).

Berdasarkan keterangan informan, peneliti menemukan salah satu yang menjadi kendala dalam menjalankan usaha pedagang kaki lima informan Ibu Iyan Dari iniadalah kurangnya skil atau keterampilan, salah satu penyebabnya ibu iyan dari hanya sekolah hanya sampai pada sekolah dasar ditambah minimnya pengalaman dalam berdagang, sehingga usahanya menjadi monoton. Terlepas dari kendala keterampilan informan juga mengalami permasalan di permodalan karna untuk merombak dagangan itu mesti harus ada dana atau modal uang utamanya gaji tukang.

\section{KESIMPULAN}

Peran Pedagang Kaki Lima (PKL) dalam menigkatkan kesejahteraan keluarga di kawasan Objek Wisata Pantai Mutiara Desa Gumanano Kecamatan Mawasangka Kabupaten Buton Tengah dapat meningkatkan pendapatan keluarga sehingga dapat membantu dalam pemenuhan kebutuhan pangan, sandang, papan, kesehatan dan pendidikan yaitu sebagai berikut :

a. Kebutuhan pangan bagi keluarga dapat terpenuhi melalui usaha sebagai Pedagang Kaki Lima (PKL) Karena pendapatan yang diperoleh dapat memenuhi kebutuhan makanan keluarga sehari-hari. b. Sandang dan papan juga menjadi terbantu dari usaha pedagang kaki lima yang di jalankan oleh masyarakat Desa Gumanano dari nominal laba yang di peroleh menjadi pemenuh kebutuhan seharihari.

c. Peran Pedagang Kaki Lima (PKL) dari sisi kesehatan juga sangat membantu dari hasil pendapatannya sebagai upaya pemenuhan kebutuhan kesehatan walaupun kadangkala mereka juga berobat secara tradisional seperti berobat pada para normal (dukun).

d. Kebutuhan pendidikan anak sampai pada Tingkat Sekolah Menengah Atas (SMA), Usaha Pedagang Kaki Lima (PKL) tersebut dapat membantu dalam memenuhi kebutuhanakan pendidikan anak. Misalnya dari segi kebutuhan pakayan sekolah dan biaya sekolah.

2. Kendala-kendala yang dihadapi Pedagang Kaki Lima (PKL) dalam meningkatkan kesejahteraan keluarga di Kawasan objek wisata Pantai Mutiara Desa Gumanano Kecamatan Mawasangka Kabupaten Buton Tengah

a. Kendala Modal menjadi kendala pedagang kaki lima di kawasan Objek Wisata Pantai Mutiara dalam meningkatkan kesejahteraan keluarg tersebut adalah pengadaan modal usaha. Modal usaha yang di pakai sangat kecil sehingga, dengan modal seadanya pedagang kaki lima (PKL) di objek wisata pantai mutiara Desa Gumanano memanfaatkanya untuk membuka usaha seadanya.

b. Kendala Pengetahuan, juga di alami oleh para pedagang kaki lima di kawasan objek wisata pantai mutiara desa gumanano, utamanya di latar belakangi factor pendidikan, dimana 
mereka rata-rata hanya sampai pada pendidikan dasar.

c. Kendala Keterampilan juga di alami oleh para pedagang kaki lima di kawasan objek wisata pantai mutiara sehingga hal demikian juga mempengaruhi kemajuan usaha mereka.

\section{DAFTAR PUSTAKA}

Damayanti, Ifany. 2011. Analisis FaktorFaktor Yang Mempengaruhi Pendapatan Pedagang di Pasar Gede Kota Surakarta. Surakarta. Universitas Sebelas Maret

Harningsih, Dkk. 2008.Dampak Relokasi Pedagang Kaki Lima di Kawasan Simpang Lima Kota Semarang. Semarang. Universitas Diponegoro

Pasal 1 ayat 1 Undang-Undang Nomor 11

Tahun 2009 tentang Kesejahteraan Sosial

Siswanto, Dwi. 2013. Faktor-Faktor Yang Mempengaruhi Pendapatan Sopir Angkutan Pedesaan Terminal Arjasa Kabupaten Jember. Jember. Universitas Jember

Sugiyono, (2008).Metode Penelitian Kuantitatif, Kualitatif dan R\&D, Bandung: Alfabeta.

Susilo, Agus. 2011. Faktor-Faktor Yang Mempengaruhi Pedagang Kaki Lima Menempati Bahu Jalan Di Kota Bogor (Studi Kasus Pedagang Sembako Di Jalan Dewi Sartika Utara). Jakarta. Universitas Indonesia 